\title{
Monitoring of Antioxidative Effect of Morine in Alloxan-induced Diabetes mellitus in the Laboratory Rat
}

\author{
L. BARTOŠÍKOVÁ, J. NEČAS, V. SUCHÝ, R. KUBÍNOVÁ, D. VESELÁ, L. BENEŠ, \\ T. BARTOŠÍK *, J. ILLEK **, J. ŠALPLACHTA***, J. KLUSÁKOVÁ*, L. BARTOŠOVÁ, \\ V. STRNADOVÁ, P. FRÁŇA*, J. FRÁŇOVÁ: \\ Faculty of Pharmacy, University of Veterinary and Pharmaceutical Sciences, Brno \\ * St. Anne Teaching Hospital, Brno \\ ** Faculty of Veterinary Medicine, University of Veterinary and Pharmaceutical Sciences, Brno \\ *** Faculty of Veterinary Hygiene and Ecology, University of Veterinary and Pharmaceutical Sciences, Brno, \\ Czech Republic
}

Received July 4, 2002

Accepted March 25, 2003

\begin{abstract}
Bartošíková L., J. Nečas, V. Suchý, R. Kubínová, D. Veselá, L. Beneš, T. Bartošík, J. Illek, J. Šalplachta, J. Klusáková, L. Bartošová, V. Strnadová, P. Fráňa, J. Fráňová: Monitoring of Antioxidative Effect of Morine in Alloxan-induced Diabetes mellitus in the Laboratory Rat. Acta Vet. Brno 2003, 72: 191-200.
\end{abstract}

The purpose of the study was to monitor the antioxidative effect of morine in alloxan-induced diabetes mellitus in laboratory rat. The animals were divided by random selection into two groups $(\mathrm{n}=7)$. The treated group was given morine in oral doses of $10 \mathrm{mg} / \mathrm{kg}^{-1}$ in $0.5 \%$ solution of Methocel E5 once a day; the control diabetic group was given only the solution of Methocel E5. Once a week, selected laboratory indices were determined in all animals (glucose, urea and cholesterol levels in serum, total glucose and protein losses through urine); diuresis as well as antioxidative enzymes (superoxiddismutase, glutathione peroxidase); total antioxidative capacity and malondialdehyde level in the blood. On the $20^{\text {th }}$ day the animals were exsanguinated and kidney tissue and pancreas samples were taken for histopathological analysis.

We found a significant increase $(p \leq 0.05)$ of the glutathione peroxidase catalytic activity in the treated group compared to control diabetic group. There was also a highly significant increase ( $p \leq$ $0.01)$ of total antioxidative capacity in the treated group compared to control diabetic group. A significant decrease $(p \leq 0.05)$ of malondialdehyde level was identified in the treated group compared to the control diabetic group. The superoxiddismutase catalytic activity involved nonsignificant changes. A significant decrease $(p \leq 0.05)$ of cholesterol level in serum was identified in the treated group compared to control diabetic group. Other examined laboratory parameters did not exhibit significant changes.

Biochemical indices followed in this study indicated a protective antioxidative effect of morine. However, the results of histopathological examination did not correlate with them.

Free radicals, morine, diabetes mellitus, malondialdehyde, antioxidative enzymes

The role of free radicals and antioxidants in human organisms has been discussed in specialized literature for more than 10 years (Opltová et al. 2000). Antioxidants act preventively against the formation and action of reactive oxygen and nitrogen radicals, i.e. substances that are formed in vivo and cause damage to DNA, lipids, proteins and other molecules. Oxidative damage of cells and tissues plays an important role in the etiology of the majority of so-called civilization diseases (Holeček and Racek 1994). Endogenous antioxidation protection of the human organism, e.g. in the form of superoxide dismutase and enzymes eliminating hydrogen peroxide or of metal-binding proteins, is insufficient due to the modern way of life in developed countries. Particularly effective appears to be the method consisting in minimizing the sources of the formation of free radicals and strengthening of natural antioxidation mechanisms by administration of substances that act as antioxidants or 
so-called free radical extinguishers (Kubínová and Suchý 1999). Therefore, when studying substances with antioxidative effect, special attention is paid to the search for such substances that could be used especially in prevention, i.e. in so-called radical-conditioned states (Nečas et al. 1997; B artošíková et al. 1998).

Experimental studies of the effect of potential antioxidants in vivo are carried out on pathological biomodels and in conditions in the pathogenesis of which significant participation of free radicals has been proven. Diabetes mellitus is one of the pathological conditions that are always accompanied by oxidative stress, i.e. with the preponderance of oxidative reactions over the antioxidative protection of tissues (Sinclair 1993). Increased production of reactive forms of oxygen and lipoperoxides together with lowered levels of substances having antioxidative action (vitamin $\mathrm{C}$, vitamin E, lipoic acid, glutathione) and enzymes acting as antioxidative agents, such as superoxiddismutase, catalase (Giugliano et al. 1996; Packer et al. 1995; W ohaieb and Godin 1987) can be found in the blood and tissues of patients affected with the disease. According to current views the antioxidative stress plays a significant role in the etiopathogenesis of diabetes of both $1^{\text {st }}$ and $2^{\text {nd }}$ types and has key importance in the occurrence and development of diabetic complications.

Flavonoids are a group of polyphenolic substances, very widespread in nature, which are found in plants predominantly in the form of glycosides. Especially aglycones are pharmacologically effective. Many of them show hepatoprotective, diuretic, vasodilation, antibacterial and chemoprotective effects; anti-inflammatory, antidiabetic, antiallergic, and other effects have also been described (Calomme et al. 1996; Read 1995; Perez et al. 1998; Yamamura et al. 1998). In recent years, increased attention has been paid to the study of their antioxidative activity and capability to extinguish or absorb free radicals (Jovanovic et al. 1994; Rice-Evans et al. 1995; Catapano 1997).

Morin (3, 3', 5, 5, 7 - pentahydroxyflavon) - $\mathrm{C}_{15} \mathrm{H}_{10} \mathrm{O}_{7}$ is a component substance of Morus tinctoria L., from which it was isolated.

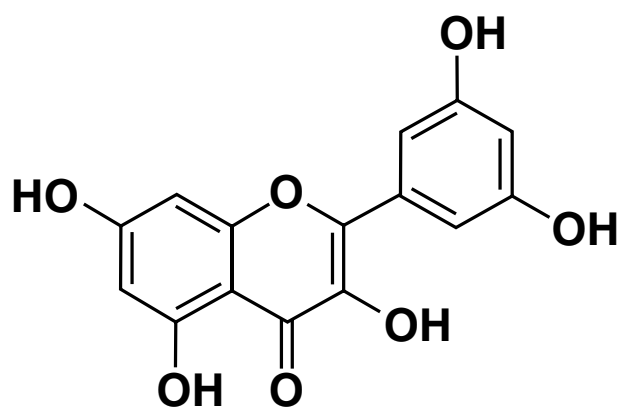

\section{$\mathrm{C}_{15} \mathrm{H}_{10} \mathrm{O}_{7}$}

$\mathrm{MW}=\mathbf{3 0 2 . 2 3 9 8}$

Fig. 1. Chemical structure of morine

In vitro testing confirmed its chemoprotective (Kawabata et al. 1999), antimutagenic (Choi et al. 1994), antivirotic (B uny apraphats ara et al. 2000) and antioxidative activities (Sugihara et al. 1999). In our in vitro tests the antioxidative effect of morine was examined by the method of determination of lipid peroxidation in laboratory rat liver microsomes using buthylhydroxytoluene (BHT) as reference standard (U chiy a ma and Mih ara 1978). Further, morine antioxidative activity in vitro was determined using diphenyl-picryl-hydrazyl radical [DPPH] (Blais 1958). The results of these experiments gave impetus to further research. 
The aim of the present work was to monitor antioxidative effect of morine in alloxaninduced diabetes mellitus in laboratory rat.

The study itself and its course were approved and monitored by the Ethical Committee of the University of Veterinary and Pharmaceutical Sciences. The state of health of all animals was regularly examined several times a day both during the period of the acclimation of the animals and during the whole course of the experiment by the working team whose members are holders of the Certificate on Professional Competence issued by the Central Commission for the Animal Protection pursuant to $\S 17$ of the Act on Protection of Animals against Cruelty (No. 246/1992 Coll.) of the Czech National Council.

\section{Materials and Methods}

The in vivo study itself was performed on 14 male laboratory rats of the Wistar SPF line (AnLab s.r.o., Brno), of identical age and comparable weight $(300 \pm 14 \mathrm{~g})$. The animals were placed individually in glass metabolic cages, fed a standard diet (Diet for small laboratory animals SPF M1) and given water ad libitum. After the time necessary for acclimation, alloxan tetrahydrate was administered to animals intravenously in a single dose of $50 \mathrm{mg} / \mathrm{kg}$. After 5 days, glycaemia levels were determined using Glucochir device and Glucocard diagnostic testing strips. The animals whose blood sugar level increased from the initial value of $4-6 \mathrm{mmol} / \mathrm{l}$ to $18 \pm 4 \mathrm{mmol} / \mathrm{l}$ were included in the experiment. Animals were split up into 2 groups using random selection. The treated group $(n=7)$ was administered morine in the dose of $10 \mathrm{mg} / \mathrm{kg}$ in $0.5 \%$ Methocel E 5 solution once a day orally. The control diabetic group $(\mathrm{n}=7)$ was only administered $0.5 \%$ Methocel $\mathrm{E} 5$ solution in the dose of $2 \mathrm{ml}$, again orally once a day. Once a week, selected laboratory parameters were determined in all the animals (glucose, urea and cholesterol levels in serum) by spectrophotometry using Diagnostika Lachema laboratory testing sets, as well as antioxidative enzymes (superoxiddismutase, glutathione peroxidase) and total antioxidative capacity by COBAS MIRA S automatic analyser, using RANDOX Dublin Ireland comp. testing sets. The malondialdehyde level in serum was also determined by spectrophotometry using TBARs method (Kosugy and Kikugava 1989) once at the end of the therapy. Then diuresis and total glucose and protein losses through urine were monitored by spectrophotometry using Diagnostika Lachema testing sets.

On the $20^{\text {th }}$ day, on completion of the medication, the animals were exsanguinated and kidney tissue and pancreas samples were taken for histopathological analysis. Samples were fixed in neutral $10 \%$ formol and routinely stained by hematoxyline-eosine. Preparations were examined in an optical microscope.

The obtained values of monitored laboratory parameters were processed using Microsoft Excel spreadsheet and statistically evaluated using UNISTAT 5.1 software and unpaired T-test; a value of $p \leq 0.05$ was considered significant.

\section{Results}

\section{Results of laboratory examinations}

Table 1a

Monitored laboratory parameter values before treatment

\begin{tabular}{|l|c|c|c|}
\hline $\begin{array}{l}\text { Monitored parameter } \\
\text { before treatment }\end{array}$ & $\begin{array}{c}\text { SOD } \\
{[\mathrm{U} / \mathrm{ml}]}\end{array}$ & $\begin{array}{c}\text { GSHPx } \\
{[\mu \mathrm{kat} / \mathrm{l}]}\end{array}$ & $\begin{array}{c}\text { AOC } \\
{[\mathrm{mmol} / \mathrm{l}]}\end{array}$ \\
\hline Treated group $(\mathrm{n}=7)$ & $216.68 \pm 48.20$ & $1133.29 \pm 117.02$ & $1.06 \pm 0.03$ \\
\hline Control diabetic group $(\mathrm{n}=7)$ & $243.97 \pm 20.23$ & $1196.00 \pm 166.36$ & $1.10 \pm 0.16$ \\
\hline Statist. significance & $\mathrm{ns}$ & $\mathrm{ns}$ & $\mathrm{ns}$ \\
\hline
\end{tabular}

$\mathrm{SOD}=$ superoxiddismutase, $\mathrm{GSHPx}=$ glutathion peroxidase, $\mathrm{AOC}=$ total antioxidative capacity, $\mathrm{ns}=$ non-significant

Table $1 b$

Monitored laboratory parameter after treatment

\begin{tabular}{|l|c|c|c|c|}
\hline $\begin{array}{l}\text { Monitored parameter } \\
\text { after treatment }\end{array}$ & $\begin{array}{c}\text { SOD } \\
{[\mathrm{U} / \mathrm{ml}]}\end{array}$ & $\begin{array}{c}\text { GSHPx } \\
{[\mu \mathrm{kat} / \mathrm{l}]}\end{array}$ & $\begin{array}{c}\text { AOC } \\
{[\mathrm{mmol} / \mathrm{l}]}\end{array}$ & $\begin{array}{c}\text { MDA } \\
{[\mathrm{mmol} / \mathrm{l}]}\end{array}$ \\
\hline Treated group $(\mathrm{n}=7)$ & $216.82 \pm 31.50$ & $1444.43 \pm 138.39$ & $1.09 \pm 0.10$ & $1.54 \pm 0.32$ \\
\hline Control diabetic group $(\mathrm{n}=7)$ & $200.27 \pm 11.71$ & $1236.43 \pm 132.94$ & $0.90 \pm 0.07$ & $2.49 \pm 0.70$ \\
\hline Statist. significance & $\mathrm{ns}$ & $p \leq 0.05$ & $p \leq 0.01$ & $p \leq 0.05$ \\
\hline
\end{tabular}

SOD = superoxiddismutase, $\mathrm{GSHPx}=$ glutathion peroxidase, $\mathrm{AOC}=$ total antioxidative capacity,

$\mathrm{MDA}=$ malondialdehyde, $\mathrm{ns}=$ non-significant 
On completion of the therapy, a statistically significant increase in catalytic activity of glutathione peroxidase $(p \leq 0.05)$, an increase in total antioxidative capacity $(p \leq 0.01)$, but a significant decrease in MDA concentration $(p \leq 0.05)$, and non-significant changes in superoxiddismutase catalytic activity were found in the treated group as compared to the control diabetic group values.

Table 2

Monitored laboratory parameter values

\begin{tabular}{|l|c|c|c|}
\hline \multirow{2}{*}{ Monitored parameter } & \multicolumn{2}{|c|}{ Cholesterol level in serum [mmol/1] } & Statist. significance \\
& treated group & control diabetic group & \\
\hline Before $\left(1^{\text {st }}\right.$ day $)$ & $1.95 \pm 0.32$ & $1.82 \pm 0.34$ & $\mathrm{~ns}$ \\
\hline After $\left(20^{\text {th }}\right.$ day $)$ & $1.53 \pm 0.22$ & $1.89 \pm 0.36$ & $p \leq 0.05$ \\
\hline Statist. significance & $p \leq 0.01$ & $\mathrm{~ns}$ & \\
\hline
\end{tabular}

Comparing cholesterol levels in the serum of the treated and the control diabetic groups on the $1^{\text {st }}$ and $20^{\text {th }}$ day of the experiment, a significant decrease in the monitored parameter $(p \leq 0.05)$ was detected in the group treated with morine. Comparing the levels acquired in the treated group before and after the treatment with morine using paired t-test, highly significant difference of the monitored laboratory parameter $(p \leq 0.01)$ was identified.

Table 3

Monitored laboratory parameter values

\begin{tabular}{|c|c|c|c|}
\hline \multirow[t]{2}{*}{ Monitored parameter } & \multicolumn{2}{|c|}{ Glucose level in serum [mmol/1] } & \multirow[t]{2}{*}{ Statist. significance } \\
\hline & treated group & control diabetic group & \\
\hline Before ( $1^{\text {st }}$ day $)$ & $19.31 \pm 0.73$ & $19.50 \pm 0.52$ & ns \\
\hline $\operatorname{After}\left(20^{\text {th }}\right.$ day $)$ & $19.31 \pm 0.52$ & $19.95 \pm 0.52$ & $\mathrm{~ns}$ \\
\hline
\end{tabular}

Comparing glucose levels in the serum of the treated group and the control diabetic group on the $1^{\text {st }}$ and $20^{\text {th }}$ day of the experiment, no significant differences were found.

Table 4

Monitored laboratory parameter values

\begin{tabular}{|l|c|c|c|}
\hline Monitored parameter & \multicolumn{2}{|c|}{ Total losses of glucose in the urine [mmol/l] } & Statist. significance \\
& treated group & control diabetic group & \\
\hline Before $\left(1^{\text {st }}\right.$ day $)$ & $1.49 \pm 0.63$ & $1.35 \pm 0.95$ & $\mathrm{~ns}$ \\
\hline After $\left(20^{\text {th }}\right.$ day $)$ & $1.17 \pm 0.45$ & $1.13 \pm 0.54$ & $\mathrm{~ns}$ \\
\hline
\end{tabular}

Comparing the total losses of glucose in the urine of the treated and the control diabetic groups on the $1^{\text {st }}$ and $20^{\text {th }}$ day of the experiment, no significant differences were detected.

Table 5

Monitored laboratory parameter values

\begin{tabular}{|l|c|c|c|}
\hline \multirow{2}{*}{ Monitored parameter } & \multicolumn{2}{|c|}{ Urea level in serum [mmol/1] } & Statist. significance \\
& treated group & control diabetic group & \\
\hline Before $\left(1^{\text {st }}\right.$ day $)$ & $5.95 \pm 1.01$ & $5.37 \pm 0.67$ & $\mathrm{~ns}$ \\
\hline After $\left(20^{\text {th }}\right.$ day $)$ & $6.09 \pm 1.62$ & $6.45 \pm 1.42$ & $\mathrm{~ns}$ \\
\hline
\end{tabular}


Comparing the urea levels of the treated and the control diabetic groups on the $1^{\text {st }}$ and $20^{\text {th }}$ day of the experiment, no significant differences were found.

Table 6

Monitored laboratory parameter values

\begin{tabular}{|l|c|c|c|}
\hline \multirow{2}{*}{ Monitored parameter } & \multicolumn{2}{|c|}{ Diuresis [ml/day] } & Statist. significance \\
& treated group & control diabetic group & \\
\hline Before $\left(1^{\text {st }}\right.$ day $)$ & $17.09 \pm 4.56$ & $18.57 \pm 7.30$ & $\mathrm{~ns}$ \\
\hline After $\left(20^{\text {th }}\right.$ day $)$ & $17.24 \pm 2.80$ & $17.22 \pm 3.31$ & $\mathrm{~ns}$ \\
\hline
\end{tabular}

Comparing diuresis within 24 hours of the treated and the control diabetic groups on the $1^{\text {st }}$ and $20^{\text {th }}$ day of the experiment, no significant differences were found.

Table 7

Monitored laboratory parameter values

\begin{tabular}{|l|c|c|c|}
\hline \multirow{2}{*}{ Monitored parameter } & \multicolumn{2}{|c|}{ Total protein losses in the urine $[\mathrm{g} / \mathrm{l}]$} & Statist. \\
& treated group & control diabetic group & \\
\hline Before $\left(1^{\text {st }}\right.$ day $)$ & $0.28 \pm 0.22$ & $0.37 \pm 0.22$ & $\mathrm{~ns}$ \\
\hline After $\left(20^{\text {th }}\right.$ day $)$ & $0.25 \pm 0.08$ & $0.35 \pm 0.30$ & $\mathrm{~ns}$ \\
\hline
\end{tabular}

Comparing the total protein losses in the urine of the treated and the control diabetic groups on the $1^{\text {st }}$ and $20^{\text {th }}$ day of the experiment, no significant differences were found.

Results of histopathological analyses

Kidney tissue

Using histopathological preparations, we evaluated the level of damage to the cortical and medullary parts of kidney parenchyma, in particular the condition of all parts of proximal tubules, the content in their lumina, the condition of epithelia, their oedema, loss of the brush border, pyknosis of the cores and loss of their stainability.

The changes were evaluated semiquantitavely in terms of the extent and intensity of damage of several tubules as light, medium and heavy.

\section{The treated group}

Slight oedematous seepage of the parenchyma and slight congestion as the manifestation of medullary changes occurred in $60 \%$. Changes in glomeruli in terms of their increased cellularity caused by the presence of erythrocytes and repletion of mesangia were observed in approximately $40 \%$. In both examined groups, vascular changes consisting in a slight thickening of the wall of medium and large vessels could be found in $20 \%$ of the cases. Histological changes were evaluated as minimum and non-significant.

\section{The control group}

In the medulla, vacuolar degeneration of the proximal tubule epithelia with slight congestion were detectable only focally in $80 \%$. In the cortex, both the changes of glomeruli and vascular changes could be observed. In the case of glomeruli, there were changes of their cellularity, namely their increase (erythrocytes, inflammatory infiltrates and repletion of mesangial cells) or decrease (hyalinization with the formation of eosinophilic deposits - similarity to Kimmelstiel-Wilson syndrome). Decreased cellularity of glomeruli is rather the manifestation of a long-term course of the disease: indications occurred in about $10 \%$ of the cases in the monitored group. Increased cellularity represented here predominantly by erythrocytes occurred in $40-50 \%$ of cases. 
Histological changes were evaluated as minimum and non-significant.

\section{Pancreas}

The treated group

There was normal structure in both the externally and internally secretoric parts without fibrosis and infiltrations.

The control group

Slight variations in the size and number of islets, sporadically mitotic activity of beta cells was revealed. Neither fibrosis (giving evidence of a long-term process), no inflammatory lymphocytic infiltration occurring regularly in infection-induced diabetes was detected.

Histological changes are quite minimal and not of a distinctive character. Even the slight variability in the size and number of islets has to be evaluated cautiously in view of the fact that these values vary depending on the place (head of the pancreas $\times$ body of the pancreas) of the collection.

\section{Discussion}

Diabetes mellitus is a syndrome initially characterized by a loss of glucose homeostasis. The disease is progressive and is associated with high risk of atherosclerosis, kidney and nerve damage as well as blindness. Abnormalities in the regulation of peroxide and transition metal metabolism are postulated to result in the development of the disease as well as its longerterm complications. Diabetes mellitus is associated with oxidative reactions, particularly those which are catalysed by decompartmentalized transition metals, but their causative significance in diabetic tissue damage remains to be established (Wolff 1993).

Much of the evidence concerning the role of oxidation in the induction of diabetes mellitus comes from the studies of alloxan which produces diabetes in experimental animals (Wolff 1993). The drug appears to selectively destroy the islets of Langerhans by oxidant production. Current evidence suggests that the selective cytotoxicity of alloxan is due to the function of 3 factors: efficient uptake, oxidant production by redox coupling of the drug with intracellular reductant (ascorbate and thiols) coupled with low levels of glutathione peroxidase in the islets (Malaisse 1982). Alloxan toxicity in vitro and in vivo can be inhibited by metal-chelating agents, hydroxyl radical scavengers and lipid-soluble antioxidants (Malaisse 1982; Wolff 1993).

Alloxan-induced diabetes mellitus served as pathological biomodel for testing a substance with supposed antioxidative activity in vivo. Elevation of the glucose level in the serum, established at the beginning of the experiment and monitored in the course of the experiment, was a conclusive proof of the experimentally produced pathological condition by the help of alloxan. Similarly, glycosuria resulting from the excess of the renal threshold for glucose determined at the beginning of the experiment and monitored during its course, also gives evidence of the diabetes production. When comparing the values of the treated group with those of the control diabetic group, statistical evaluation of the variations of both parameters showed that the changes had been non-significant both at the beginning and at the end of the experiment.

The examination of selected laboratory parameters (SOD, GSHPx, AOC and MDA) showed an increase in values of antioxidation system indicators, especially a significant increase in GSHPx catalytic activity as well as overall antioxidative capacity. In the treated group, there was no decrease in SOD during the therapy. The analyzed enzymes act intracellularly and their activities are usually linked with each other (Machartová et al. 2000). The statistically significant increase in overall antioxidative capacity, working 
extracellularly, is apparently the result of the supplementation by the substance with proven antioxidative effect in vitro.

The results of the statistical comparison of MDA values of both groups show significant changes; in the treated group, statistically significant lower average values of this secondary toxic product of lipoperoxidation were detected, in comparison with the control diabetic group at the end of the therapy.

Diabetes mellitus is characterized by elevated glycaemia and frequently by concomitant glycosuria. The basic pathogenetic agent producing hyperglycaemia is missing or insufficient secretion of insulin or its insufficient action on the level of peripheral tissue cells. Metabolic consequences of this are reflected not only in the metabolism of saccharides, but quite often they are also manifested as disorder in the metabolism of proteins, or as the disorder of metabolism of lipids, the pathogenesis of which is, however, more difficult (Klener 1999).

During the experiment, the level of cholesterol was monitored as accessory biochemical parameter and at the same time as one of the indicators of the state of the metabolism of fats under the given artificially produced pathological condition in the laboratory rat. According to some authors the laboratory rat does not appear to be an ideal experimental animal as there is no analogy with the human organism and, moreover, the rat displays very significant differences when compared with humans (Stone et al. 1979; Siguel 1983; Nishina 1991). On the other hand, there are a number of preclinical studies in which the laboratory rat, in particular, was used as a suitable animal for testing potential hypolipidemic effects of the substances applied (Sharma 1979; Cohn et al. 1988).

As regards the potential hypocholesterolemic effect of morine, we can currently only speculate about it. Existing knowledge speaks about 5 known mechanisms of effect of the substances from the group of potential hypolipidemics. The following possible mechanisms of hypolipidemic action of morine are only hypothetical (Štipek 2000):

1. Morine could act hypocholesterolemically and hypolipidemically by a similar mechanism as statines (inhibition of hydroxymethylglutaryl coenzyme A reductase leading to a marked reduction of cholesterol synthesis at the beginning of metabolic chain) or fibrates (complete, not fully explained effect leading to the decrease in the level of lipoproteins rich in triacylglycerols).

2. Morine could act by a similar mechanism as resins (inhibition of reabsorption of bile acids in intestine, cholesterol conversion to bile acids, etc.).

3. Morine could affect liver cells by an unspecified mechanism through which it intervenes directly in cholesterol formation and thus influences its level in serum.

4. Morine could affect metabolism of fatty acids, reduce synthesis of very low density lipoproteins (VLDL) in liver and thus minimize the formation of low density lipoproteins (LDL) in circulation.

5. Morine could reduce lipoperoxidation in liver by direct antioxidative effect, this phenomenon has been shown in several other flavonoids (Sharma 1979). This hypothesis seems to be the most probable.

To explain this effect, further testing on pathologic biomodels will have to be performed. In patients with longer lasting diabetes, particularly in the so-called decompensated diabetics, we encounter the occurrence of specific and non-specific chronic complications (Anděl 2001). One of the specific chronic complications is represented by the finding of diabetic nephropathy that is characterized by proteinuria, frequent hypertension and slow gradual alteration of renal functions. Diabetic nephropathy was first described in 1936 by Kimmelstiel and Wilson as intercapillary nodular glomerulosclerosis. In a narrow sense of the word, diabetic nephropathy is referred to as microangiopathic impairment of kidneys.

As part of the experiment, the levels of urea in the serum, losses of total proteins through the urine and diuresis in the experimental animals were monitored as indicators of possible 
induced nephropathy. The changes of monitored parameters appeared to be non-significant at the beginning and end of the experiment after being statistically evaluated and compared.

Similarly, the changes in kidneys that can be evaluated histopathologically depend on the duration of diabetes and on the fact if and how diabetes was treated. In short-lasting untreated disease, affection with the character of diabetic nephrosis can be proven under certain circumstances, which is manifested microscopically by cloudy swelling, vacuolar degeneration, proximal tubule cell steatosis, basement membrane thickening and glycogen presence in Armani zone cells (Rosai 1996).

Histopathological changes in pancreas are not usually microscopically symptomatic and findings are not consistent. In juvenile diabetes, islet number can be reduced; sometimes we can find beta cell degranulation, islet fibrosis and sometimes lymphocyte infiltration. In adult diabetics, the islet number is usually normal or slightly reduced, however diabetes cannot be positively diagnosed by histological examination (Rosai 1996).

Morine is a natural substance that was so far only sporadically used for in vivo testing on pathologic biomodels. Therefore, vast majority of literature references have the character of performed in vitro studies that often compare the effects of monitored representatives of flavonoid group with each other (S u gi har a et al. 1999). There is no opportunity to compare the results obtained by us during morine testing on alloxan diabetes model in our preclinical experiment with other authors' results.

Extension of knowledge about antioxidative effects of flavonoids in vitro leads to the conclusion that pathological impact of free radicals can be influenced or reduced if we succeed to prevent their formation or their effect on cell membranes connected with their disintegration and subsequent dysfunction.

Currently there are a number of substances that are able to absorb or extinguish free radicals. One of them is morine, the antioxidative activity of which has been proved during in vitro testing.

The results of the presented study indicate a positive antioxidative effect in vivo of the tested flavonoid morine in the conditions of alloxan-induced diabetes mellitus. The results obtained from experiments could become an impulse for further preclinical analyses with subsequent verification of the effect of this substance in clinical practice.

\section{Sledování antioxidačního efektu morinu u alloxanem navozeného diabetes mellitus u laboratorního potkana}

Záměrem pilotní studie bylo sledovat antioxidační efekt morinu za podmínek alloxanem navozeného diabetes mellitus u laboratorního potkana. Zviŕata byla metodou náhodného výběru rozdělena do dvou stejných skupin $(\mathrm{n}=7)$. Skupině léčené byl podáván morin v dávce $10 \mathrm{mg} \cdot \mathrm{kg}^{-1} \mathrm{v} 0,5 \%$ roztoku Methocelu E 5 perorálně $1 \mathrm{x}$ denně, skupině kontrolní byl podáván pouze roztok Methocelu E 5. Jednou týdně byly u zvírat stanovovány vybrané laboratorní parametry (glukosa, urea a cholesterol v séru, ztráty glukózy a bílkovin močí), diuréza, antioxidační enzymy (superoxiddismutáza, glutathionperoxidáza), celková antioxidační kapacita a hladina malondialdehydu. 20. den experimentu byla zviřata utracena vykrvením a byly odebrány vzorky ledvinné tkáně a pankreatu pro histopatologické vyšetření.

Byl zjištěn statisticky významný vzestup $(p \leq 0.05)$ katalytické aktivity glutathionperoxidázy a statisticky vysoce významný vzestup $(p \leq 0.01)$ celkové antioxidační kapacity u léčené skupiny ve srovnání se skupinou diabetickou kontrolní. Dále byl zjištěn statisticky významný pokles hladiny malondialdehydu $(p \leq 0.05)$ u léčené skupiny ve srovnání se skupinou diabetickou kontrolní. Katalytická aktivita superoxiddismutázy vykázala nesignifikantní změny. Byl zjištěn statisticky významný pokles $(p \leq 0.05)$ hladiny cholesterolu v séru u léčené skupiny ve srovnání se skupinou diabetickou kontrolní. Ostatní sledované laboratorní parametry vykázaly nesignifikantní změny. Výsledky biochemického 
vyšetření ukazují na protektivní antioxidační efekt morinu. Histopatologické nálezy s těmito výsledky nekorelují.

\section{Acknowledgements}

The study was supported by IGA MZ ČR grant - NL/5881-3.

\section{References}

ANDĚL, M et al. 2001: Diabetes mellitus. Galen, Praha, 78 p.

BARTOŠÍKOVÁ, L, NEČAS, J, PAVLÍČEK, V, KUCHTIČKOVÁ, S, FRÁŇA, P, ZAVADILOVÁ, R, HUŠEK, K 1998: Study of the effect of the sympatholytic carvedilol in the conditions of experimental alloxan diabetes in the laboratory rat. Ces a Slov Farm 47: 151-154

BLAIS, MS 1958: Antioxidant determination by the use of stable free radical. Nature 181: 1199-1200

BUNYAPRAPHATSARA, N, DECHSREE, S, YOOSOOK, C, HERUNSALEE, A, PANPISUTCHAI, Y 2000: Anti-herpes simplex virus component isolated from Maclura cochinchinensis. Phytomed 6: 421-424

CALOMME, M, PIETERS, L, VLIETINCK, A, VANDEN BERGHE, D 1996: Inhibition of bacterial mutagenesis by Citrus flavonoids. Planta Med 62: 222-226

CATAPANO, AL 1997: Antioxidant effect of flavonoids. Angiol 48: 39-44

CHOI, JS, PARK, KY, MOON, SH, RHEE, SH, YOUNG, HS 1994: Antimutagenic effect of plant flavonoids in the Salmonella assay system. Arch Pharm Res 17: 71-75

COHN, W et al. 1988: $\alpha$-tocoferol is secreted from rat liver in very low density lipoproteins. J Lipid Res 29: 13591366

GIUGLIANO, D, CERIELLO, A, PAOLISO, G. 1996: Oxidative stress and diabetic vascular complications. Diabet Care 19: 257-267

HOLEČEK, V, RACEK, J 1994: The protection against free radicals by antioxidants, trace elements and drugs. Klin Biochem Metab 2: 137-141

JOVANOVIC, SV, STEENKEN, S, TOSIC, M, MARJANOVIC, B, SIMIC, MG 1994: Flavonoids as antioxidants. J Am Chem Soc 116: 4846-4851

KAWABATA, K, TANAKA, T, HONJO, S ET AL. 1999: Chemopreventive effect of dietary flavonoid morin on chemically induced rat tongue carcinogenesis. Int J Cancer 83: 381-386

KLENER, P ET AL. 1999: Internal Medicine. Galen, Praha, 725 p.

KOSUGY, H, KIKUGAVA, K 1989: Potential thiobarbituric acid-reactive substances in peroxidized lipids. Free Rad Biol Med 7: 205-207

KUBÍNOVÁ, R, SUCHÝ, V 1999: Antioxidants of biogenic origin. Ces a Slov Farm 48: 9-14

LIPTÁKOVÁ, A, ULIČNÁ, O, DURAČKOVÁ, Z, BOŽEK P, VANČOVÁ, O 2001: Effect of Losartan on the antioxidant status of rats with diabetes mellitus. Ces a Slov Farm 50: 193-196

MACHARTOVÁ, V, RACEK, J, KOHOUT, J, SENFT, V, TREFIL, L 2000: Effect of antioxidant treatment on indicators of free radical action in workers exposed to lead. Vnitr Lek 46: 444-446

MALAISSE, WJ 1982: Alloxan toxicity of the pancreatic B-cell- a new hypothesis. Biochem Pharmacol 22: 3527 - 3534

NEČAS, J, BARTOŠÍKOVÁ, L et al. 1997: Experimental investigation of the action of the beta-blocker carvedilol in ischemic-reperfusion renal damage. Vnitr Lek 43: 707-711

NISHINA, PM ET AL. 1991: Effects of dietary fibers on nonfasting plasma lipoprotein and apolipoprotein levels in rats. J Nutr 121: 431-437

OPLTOVÁ, L, HLÚBIK, P, CHALOUPKA, J, PAVLÍK, V 2000: Antioxidants in selected Czech population. Ateroskler 4: 61-65

PACKER, L, WITT, EH, TRITSCHLER, HJ 1995: Alpha-lipoic acid as a biological antioxidant. Biol Med 19: 227-250

PEREZ, RM, ZAVAL, MA, PEREZ, S, PEREZ, C 1998: Antidiabetic effect of compounds isolated from plants. Phytomed 5: 55-57

READ, MA 1995: Flavonoids: Naturally occuring anti-inflammatory agents. Am J Pathol 147: 235-237

RICE-EVANS, CA, MILLER, NJ, BOLWELL, PG, BRAMLEY, PM, PRIDHAM, JB 1995: The relative antioxidant activities of plant-derived polyphenolic flavonoids. Free Rad Res 22: 375-383

ROSAI, J 1996: Ackerman's Surgical Pathology. St. Louis - Mosby, Vol. I - II., $8^{\text {th }}$ ed., 2732 p.

SHARMA, RD 1979: Isoflavones and hypercholesterolemia in rats. Lipids 14: 535-540

SIGUEL, EN 1983: Cancerostatic effect of vegetarian diets. Nutr Cancer 4: 285-291

SINCLAIR, AJ 1993: Free radical mechanisms and vascular complications of diabetes mellitus. Diabet Rev 2: 7-11

ŠTÍPEK, S et al. 2000: Antioxidants and free radicals in health and illness. Grada Publishing, $1^{\text {st }}$ ed., 66 p.

STONE, KJ et al. 1979: The metabolism of dihomo-gamma-linolenic acid in man. Lipids 14: 174-180

SUGIHARA, N, ARAKAWA, T, OHNISHI, M, FURUNO, K 1999: Anti- and pro-oxidative effects of flavonoids on metal-induced lipid hydroperoxide-dependent lipid peroxidation in cultured hepatocytes loaded with alphalinolenic acid. Free Radic Biol Med 27: 1313-1323 
UCHIYAMA, M, MIHARA, M 1978: Determination of malondialdehyd precursor in tissues by thiobarbituric acid test. Anal Biochem 78: 271-278

WOHAIEB, SA, GODIN, DV 1987: Alterations in free radicals tissue-defense mechanisms in streptozocininduced diabetes in rat. Effects of insulin treatment. Diabetes 36: 1014-1018

WOLFF, SP 1993: Diabetes mellitus and free radicals. British Med Bull 49: 642-652

YAMAMURA, S, OZAWA, K, OHTANI, K, KASAI, R, YAMASKI, K 1998: Antihistaminic flavones and aliphatic glycosides from Mentha spicata. Phytochem 48: 131-136 